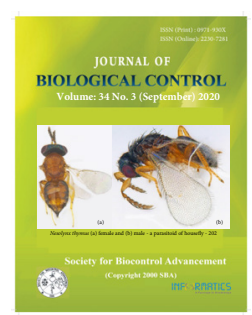

Research Article

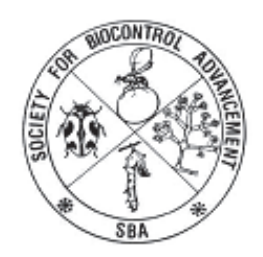

\title{
Biocontrol potential of three antagonists against downy mildew of pearl millet caused by Sclerospora graminicola (Sacc.) Schoret
}

\author{
K. K. SAINI ${ }^{1 *}$, A. C. MATHUR ${ }^{1}$, R. S. SHARMA ${ }^{1}$, VIRENDRA KUMAR ${ }^{1}$, R. K. BAGRI ${ }^{1}$ and VISHNU GAUTUM ${ }^{2}$ \\ ${ }^{1}$ Division of Plant Pathology, Rajasthan Agricultural Research Institute, Durgapura, Jaipur - 302018, Rajasthan, India \\ ${ }^{2}$ Residue Analysis Laboratory, Division of Entomology, Durgapura, SKN Agriculture University, Jobner, Jaipur - 303329, \\ Rajasthan, India \\ *Corresponding author E-mail: kamalsainipathology@gmail.com
}

\begin{abstract}
The efficacy of three bio-control agents viz., Trichoderma viride, Trichoderma harzianum and Pseudomonas fluorescens were evaluated against downy mildew of pearl millet in glasshouse as well as in field conditions at research farm, Rajasthan Agricultural Research Institute, Durgapura (Jaipur) during cropping seasons of kharif 2016 and 2017. The seed treatment with Trichoderma viride (@ 6 g/kg seed) followed by one spray of Pseudomonas fluorescens (@1 1 10 $\mathrm{cfu} / \mathrm{ml}$ ) 21 days after sowing significantly reduced the downy mildew incidence and increased the grain and fodder yield. Seed treatment with Trichoderma harzianum followed by one spray of Pseudomonas fluorescens (@ $\left.1 \times 10^{8} \mathrm{cfu} / \mathrm{ml}\right) 21$ days after sowing were the next in reducing the downy mildew incidence at significant level.
\end{abstract}

KEY WORDS: Biocontrol agents, downy mildew, pearl millet, Pseudomonas, Trichoderma

(Article chronicle: Received: 03-09-2020; Revised: 28-09-2020; Accepted: 30-09-2020)

\section{INTRODUCTION}

Pearl millet is a staple food for millions of poor people living in the semi-arid tropical regions of Africa and Asia (Rachie and Mujumdar, 1980). Pearl millet is grown for both fodder and grain in Asian and African countries, whereas it is solely cultivated as a forage crop in South America, U.S.A., Canada, South Africa, Italy, Japan, Australia, etc. (Johnson et al., 1976). Besides food for human consumption, the grain is also used for poultry feed and some industrial uses. A large number of diseases viz., downy mildew, ergot, smut, blast and rust (Raj et al., 2014) are reported to attack pearl millet crop. Among these, downy mildew is one of the most important diseases of pearl millet crop and cause considerable economic yield losses. It is the most widespread and destructive disease of pearl millet in India and western Africa. The disease, first reported in India (Butler, 1907), is present in more than 20 countries (Safeeulla, 1976), and is a major factor limiting the full exploitation of the high yielding hybrids in India. The disease normally appears in the form of chlorosis at the base of infected leaf followed by production of sporulation on the lower side of leaves known as the "half-leaf" symptom. Abundant white asexual sporulation on the lower leaf surface of infected chlorotic leaf produce white downy growth under high relative humidity $(>95 \%)$ and moderate temperature $\left(20-22^{\circ} \mathrm{C}\right)$. Subsequently the leaves turn reddish brown due to oospore production and dry ultimately. Downy mildew causes $57 \%$ reduction in the yield besides heavy losses in the fodder yield (Gupta and Singh, 1996). Subsequent to this epidemic, grain yield losses continue to occur quite frequently due to downy mildew epidemics in India (Singh et al., 1987). It has been demonstrated that the losses in yield can be directly proportional to disease severity (Williams and Singh, 1981). Although, chemical fungicidal interventions are reported effective against this disease, growing concern for environmental pollution and residue problems in the pearl millet necessitate the search for alternative means of control. In this direction, the present investigation was carried out to study the efficacy of antagonistic organisms viz., Trichoderma viride, Trichoderma harzianum and Pseudomonas fluorescens against Sclerospora graminicola caused downy mildew of pearl millet.

\section{MATERIALS AND METHODS}

\section{Biocontrol potential of antagonists on downy mildew of pearl millet in glasshouse}

Three known antagonists' viz., Trichoderma viride, Trichoderma harzianum and Pseudomonas fluorescens procured from Biocontrol laboratory, RARI, Durgapura, Jaipur 
and tested as seed dresser as well as spray of Pseudomonas fluorescens in glass house for their antagonistic effect against Sclerospora graminicola. These fungal bio-control agents were cultured for seven days on Potato Dextrose Agar (PDA) in order to get fresh and active growth of each fungus. In case of bacterial fresh and active growth King's B medium was used. For this purpose, soil + compost (2:1) was sterilized in autoclave at $30 \mathrm{psi}$ for 30 minutes and filled in earthen pots of $30 \mathrm{~cm}$ diameter. Pearl millet cultivar (7042 S) seeds were sterilized with bleaching agent $(\mathrm{NaOCl}, 0.5 \% \mathrm{w} / \mathrm{v})$ for 30 minutes and rinsed thoroughly with sterilized water. To prepare seed treatment inoculants, a suspension of conidia in sterile water was prepared for seed treatment and sterilized seeds of highly susceptible cultivar $7042 \mathrm{~S}$ were treated separately with the conidial suspension at the rate of $20 \mu \mathrm{g} \mathrm{g}^{-1}$ to deposit $2 \times$ $10^{7} \mathrm{CFU} \mathrm{g}{ }^{-1}$ of seed. Control seed were treated with an equal amount of sterilized water. Treated seed were allowed drying them for 30 minutes before sowing in pots. Fifty seeds were sown in each pot at a depth of $0.5 \mathrm{~cm}$ from soil surface. The pots were watered regularly as and when needed and 2 sprays of Pseudomonas fluorescens (@1 1 10 cfu/ml)were done at 7 and 14 days after sowing. The experiment was conducted in Completely Randomized Design (CRD) with three replications for each treatment. Downy mildew incidence was recorded 14 days post sowing and the Per cent disease incidence was calculated using the below given formula.

Percent disease $=$ - Number of infected plants incidence Total number of plants observed

\section{Evaluation of biocontrol agents against downy mildew of pearl millet under field conditions}

The effective biocontrol agents were assessed as seed treatment for management of pearl millet downy mildew. The experiment was conducted for two seasons during kharif 2016 and kharif 2017 at Research Farm, Rajasthan Agricultural Research Institute, Durgapura (Jaipur). The moderately resistant cultivar (Nokha Local) seeds were treated with each biocontrol agent separately. The treatment without dressing with biocontrol agent served as check and seeds were sown in row-to-row $50 \mathrm{~cm}$ and plant to plant $15 \mathrm{~cm}$ apart in plot size of $3 \times 4 \mathrm{~m}$. The treatments were replicated in a Randomized Block Design (RBD) and FYM (Farmyard Manure) was applied @ 10 to 12 tones/ha at two to three week before sowing. The fertilizers, 90:30 $\left(\mathrm{N}: \mathrm{P}_{2} \mathrm{O}_{5}\right) \mathrm{kg} /$ ha were applied, in which nitrogen was applied in two equal doses as basal and top dressing at 30 days after sowing. Experiment was kept free from weeds and insect pests. Irrigation was applied as and when necessary. The other details of the experiment are as follows:

- Replications - 4

- Treatments -6
$\mathrm{T}_{1}$ : Seed treatment with T. viride (@6 g/kg seed)+1 spray of P. fluorescens (@1 x 10 cfu/ml) on 21 days old plants

$\mathrm{T}_{2}$ : Seed treatment with T. harzianum (@6 g/ $\mathrm{kg}$ seed) +1 spray of P.fluorescens (@1 x 108 cfu/ml) on 21 days old plants

$\mathrm{T}_{3}$ : Seed treatment with T. viride (@6 g/ $\mathrm{kg}$ seed)

$\mathrm{T}_{4}$ : Seed treatment with T. harzianum (@6 g/kg seed)

$\mathrm{T}_{5}$ : Seed treatment with P. fluorescens (@8 g/kg seed)

$\mathrm{T}_{6}$ : Control

\section{Observations recorded}

\section{i. Downy mildew incidence (\%)}

The total number of plants was recorded at the time of thinning i.e. fifteen days after sowing, while the number of downy mildew infected plants was recorded at 30 and 60 days after sowing. Percent incidence of downy mildew was calculated with the help of the following formula:

$\begin{aligned} & \text { Downy mildew } \\ & \text { incidence }(\%)\end{aligned}=\frac{\text { Downy mildew infected plants }}{\text { Total number of plants }} \times 100$

\section{ii. Seedling emergence}

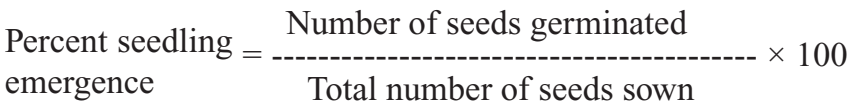

\section{iii. Grain Yield q/ha}

iv. Fodder Yield q/ha

\section{RESULTS AND DISCUSSION}

\section{Biocontrol potential of antagonists on downy mildew of pearl millet in glasshouse}

The data on seedling emergence (\%) and downy mildew incidence were recorded (Table 1). Maximum seedling emergence $(83.50 \%)$ was observed in seed treatment with T.viride (@6g/kg seed)+2 sprays of P. fluorescence (@) $1 \times 10^{8} \mathrm{cfu} / \mathrm{ml}$ ) at 7 days old plant and 14 days old plant. Other treatments showed seedling emergence in the range of $71.5-79.5 \%$, while untreated control showed the least seedling emergence $(40.50 \%)$. All treatments were reduced the downy mildew incidence significantly over control but recorded minimum (11.23\%) DM incidence in seed treatment with T. viride (@6 g/ $/ \mathrm{kg}$ seed) + 2 sprays of $P$. fluorescence (@1 x 108 cfu/ml) and the untreated control showed maximum of $40.43 \%$ downy mildew incidence. Other 
treatments showed downy mildew incidence in the range of $13.56-19.45 \%$.

\section{Evaluation of biocontrol agents against downy mildew of pearl millet under field conditions}

The pooled data on seedling emergence (\%), downy mildew incidence $(\%)$, grain yield $(\mathrm{q} / \mathrm{ha})$ and fodder yield (q/ha) recorded during kharif seasons of 2016 and 2017 are presented in Table 2.

The perusal of the data indicated that all the bio-agent treatments were significantly superior to untreated control in reducing the downy mildew incidence and increasing the yield of grains and fodder during kharif 2016 and kharif 2017 crop seasons.

Seed treatment with $T$. viride (@6 g/kg seed)+1 spray of P. fluorescens (@1x10 cfu/ml) recorded the maximum seedling emergence of $52.1 \%$ followed by seed treatment with T. harzianum (@6 g/kg seed)+1 spray of P.fluorescens (@) $1 \times 10^{8} \mathrm{cfu} / \mathrm{ml}$ ) (50.69\%), seed treatment with T. viride (@) $6 \mathrm{~g} / \mathrm{kg}$ seed) (49.68\%), seed treatment with T. harzianum (@6 g/kg seed) (48.73\%) and P. fluorescens (@8 g/kg seed) $(47.66 \%)$ in comparison to the seedling emergence in untreated control (40.63\%).

Amongst different treatments, seed treatment with $T$. viride (@6 g/kg seed)+1 spray of P.fluorescens (@1 x 10 $\mathrm{cfu} / \mathrm{ml}$ ) was significantly effective in reducing the incidence of pearl millet downy mildew to the minimum of $(6.0 \%)$ in comparison to $31.15 \%$ in control at 30 days after sowing.
Seed treatment with T. harzianum (@6 g/kg seed)+1 spray of P. fluorescens (@1 x 10 cfu/ml) ranked next (7.6\%) followed by T.viride (@6 g/kg seed) (9.15\%),T. harzianum (@6 g/kg seed) (14.10\%) and P.fluorescens (@8 g/kg seed) (11.95\%).

At 60 days after sowing, seed treatment with $T$. viride (@ $6 \mathrm{~g} / \mathrm{kg}$ seed)+1 spray of P.fluorescens (@1 x 10 cfu/ml) was significantly superior in reducing the pearl millet downy mildew incidence to the minimum of 13.71 in comparison to $39.35 \%$ in the control. Seed treatment with T. harzianum (@ $6 \mathrm{~g} / \mathrm{kg}$ seed $)+1$ spray of P. fluorescens (@1 x 10 cfu/ml) and seed treatment with T. viride (@6 g/kg seed) ranked next ( $14.71 \%$ and $16.42 \%$ respectively) in managing pearl millet downy mildew and treatment $\mathrm{T}_{1}$-seed treat with T. viride(@6 g/kg seed) + 1 spray of P. fluorescens (@1 1 10 cfu/ml)was at par with treatment $\mathrm{T}_{2}$ - Seed treatment with $T$. harzianum (@6 g/kg seed)+1 spray of P.fluorescens (@1 x 10 cfu $/ \mathrm{ml}$ ).

The results revealed that grain yield in all the treatments of biocontrol agents was significantly superior in comparison to control of $4.44 \mathrm{q} / \mathrm{ha}$. The maximum grain yield of $8.94 \mathrm{q} /$ ha was recorded with seed treatment of T. viride $(@ 6 \mathrm{~g} / \mathrm{kg}$ seed) + spray of P. fluorescens (@1 1 10 $\left.10^{8} \mathrm{cfu} / \mathrm{ml}\right)$ was at par with seed treatment of T. harzianum (@6 g/kg seed)+ spray of P. fluorescens (@1 x10 cfu/ml)(8.81 q/ha).

The fodder yield also in all treatments of biocontrol agents was significantly superior in comparison to control (37.75 q/ha). The maximum fodder yield of $51.80 \mathrm{q} / \mathrm{ha}$ was recorded on seed treatment with T.viride (@6 g/kg seed)

Table 1. Antagonistic effect of various biocontrol agents against $S$. graminicola in glasshouse

\begin{tabular}{|c|c|c|c|}
\hline Tr. No. & Microorganism & $\begin{array}{c}\text { Seedling } \\
\text { emergence }(\%)\end{array}$ & $\begin{array}{l}\text { Downy mildew } \\
\text { Incidence }(\%)\end{array}$ \\
\hline $\mathbf{T}_{1}$ & $\begin{array}{l}\text { Seed treatment with T. viride (@6 g/kg seed) + spray of P. fuorescence } \\
\left.\text { (@1 } 1 \times 10^{8} \mathrm{cfu} / \mathrm{ml}\right)\end{array}$ & $\begin{array}{l}83.50^{\mathrm{a}} \\
(66.01)^{*}\end{array}$ & $\begin{array}{r}11.23^{\mathrm{a}} \\
(19.56)\end{array}$ \\
\hline $\mathbf{T}_{2}$ & $\begin{array}{l}\text { Seed treatment with } T . \text { harzianum (@6 g/kg seed) + spray of } P \text {. fluores- } \\
\text { cence }\left(@ 1 \times 10^{8} \mathrm{cfu} / \mathrm{ml}\right)\end{array}$ & $\begin{array}{l}79.5^{\mathrm{b}} \\
(63.07)\end{array}$ & $\begin{array}{l}13.56^{\mathrm{b}} \\
(21.59)\end{array}$ \\
\hline $\mathbf{T}_{3}$ & Seed treatment with T. viride (@6 g/kg seed) & $\begin{array}{r}76.50^{c} \\
(60.99)\end{array}$ & $\begin{array}{l}15.89^{c} \\
(23.47)\end{array}$ \\
\hline $\mathbf{T}_{4}$ & Seed treatment with $T$. harzianum (@6 g/kg seed) & $\begin{array}{l}71.50^{\mathrm{d}} \\
(57.72)\end{array}$ & $\begin{array}{l}17.34^{\mathrm{d}} \\
(24.59)\end{array}$ \\
\hline $\mathbf{T}_{5}$ & Seed treatment with P. fluorescens(@6 g/kg seed) & $\begin{array}{c}73.50 \\
(59.00)\end{array}$ & $\begin{array}{c}19.45 \\
(26.15)\end{array}$ \\
\hline \multirow[t]{4}{*}{$\mathbf{T}_{6}$} & Control & $\begin{array}{c}40.50 \\
(39.50) \\
\end{array}$ & $\begin{array}{c}40.43 \\
(39.46) \\
\end{array}$ \\
\hline & $\mathrm{SEm} \pm$ & $(0.59)$ & $(0.27)$ \\
\hline & CD at $5 \%$ & $(1.77)$ & $(0.81)$ \\
\hline & CV\% & $(2.05)$ & $(2.11)$ \\
\hline
\end{tabular}

Average of four replications

*Figures in parentheses are angular transformed value 
Table 2. Evaluation of various biocontrol agents against downy mildew of pearl millet during kharif 2016 and 2017 under field conditions

\begin{tabular}{|c|c|c|c|c|c|}
\hline Treatments & $\begin{array}{l}\text { Seedling } \\
\text { emergence } \\
\quad(\%)\end{array}$ & $\begin{array}{l}\text { Downy mildew } \\
\text { incidence } \\
\text { (\%) at } 30 \text { DAS } \\
\text { (Pooled) }\end{array}$ & $\begin{array}{l}\text { Downy mildew } \\
\text { incidence } \\
\text { (\%) at } 60 \text { DAS } \\
\text { (Pooled) }\end{array}$ & $\begin{array}{l}\text { Pooled } \\
\text { grain yield } \\
\text { (q/ha) }\end{array}$ & $\begin{array}{l}\text { Pooled fodder } \\
\text { yield } \\
\text { (q/ha) }\end{array}$ \\
\hline $\begin{array}{l}\mathrm{T}_{1} \text { - Seed treatment with } T \text {. viride (@6 g/kg } \\
\text { seed) + spray of } P \text {. fluorescens } \\
\left.\text { (@1 } 1 \times 10^{8} \mathrm{cfu} / \mathrm{ml}\right)\end{array}$ & $\begin{array}{c}52.10 \\
(46.69)^{*}\end{array}$ & $\begin{array}{c}6.0 \mathrm{a} \\
(14.14)\end{array}$ & $\begin{array}{r}13.71 \mathrm{a} \\
(21.71)\end{array}$ & 8.94 & 51.80 \\
\hline $\begin{array}{l}T_{2} \text { - Seed treatment with } T \text {. harzianum } \\
(@ 6 \mathrm{~g} / \mathrm{kg} \text { seed })+\text { spray of } \\
\text { P. fuorescens }\left(@ 1 \times 10^{8} \mathrm{cfu} / \mathrm{ml}\right)\end{array}$ & $\begin{array}{c}50.69 \\
(45.38)\end{array}$ & $\begin{array}{c}7.6 b \\
(15.98)\end{array}$ & $\begin{array}{l}14.71 b \\
(22.53)\end{array}$ & 8.81 & 49.95 \\
\hline $\begin{array}{l}T_{3} \text { - Seed treatment with } T \text {. viride } \\
\text { (@ } 6 \mathrm{~g} / \mathrm{kg} \text { seed) }\end{array}$ & $\begin{array}{c}49.68 \\
(44.49)\end{array}$ & $\begin{array}{c}9.15 \mathrm{c} \\
(17.57)\end{array}$ & $\begin{array}{l}16.42 \mathrm{c} \\
(23.88)\end{array}$ & 7.85 & 47.25 \\
\hline $\begin{array}{l}T_{4} \text { - Seed treatment with } T \text {. harzianum } \\
\text { (@ } 6 \mathrm{~g} / \mathrm{kg} \text { seed) }\end{array}$ & $\begin{array}{c}48.73 \\
(44.25)\end{array}$ & $\begin{array}{l}11.95 d \\
(20.20)\end{array}$ & $\begin{array}{l}16.45 d \\
(24.29)\end{array}$ & 6.72 & 43.42 \\
\hline $\begin{array}{l}T_{5} \text { - Seed treatment with } P \text {. fluorescens } \\
\text { (@) } 8 \mathrm{~g} / \mathrm{kg} \text { seed) }\end{array}$ & $\begin{array}{c}47.66 \\
(43.64)\end{array}$ & $\begin{array}{c}14.1 \\
(22.04)\end{array}$ & $\begin{array}{c}19.43 \\
(26.14)\end{array}$ & 6.48 & 42.12 \\
\hline $\mathbf{T}_{6}-$ Control & $\begin{array}{c}40.63 \\
(39.58)\end{array}$ & $\begin{array}{c}31.15 \\
(33.91)\end{array}$ & $\begin{array}{l}39.35 \\
(38.83)\end{array}$ & 4.44 & 37.75 \\
\hline $\operatorname{SEm} \pm$ & 0.65 & 0.44 & 0.47 & 0.21 & 0.66 \\
\hline CD@5\% & 1.99 & 1.36 & 1.44 & 0.65 & 2.02 \\
\hline CV\% & 2.96 & 4.34 & 3.61 & 5.93 & 2.93 \\
\hline
\end{tabular}

All data are means of 4 replications

*Figures in parentheses are angular transformed value

+ spray of P. fluorescens (@ $1 \times 10^{8} \mathrm{cfu} / \mathrm{ml}$ ) which was at par with seed treatment of T. harzianum (@6 g/kg seed)+ spray of P.fluorescens (@1 x 108 cfu/ml) (49.95 q/ha).These findings are closely agreement with the findings of other scientists viz., Umsesha et al. (1998), Nandakumar et al. (2001), Niranjan et al. (2004), Raj et al. (2005), Latake and Kolase (2007), Mane et al. (2007), Mani and Hepziba (2009), Mani et al. (2009), Raj et al. (2011), Nandini et al. (2013), Sangwan and Kushal Raj (2016) and Sasode et al. (2018) who evaluated bioagents viz., $P$. fluorescence, T. viride and T. harzianum as seed dresser as well as spray for the control of downy mildew incidence and recorded $T$. viride and $P$. fluorescence as best in reducing the downy mildew incidence and increased the grain and fodder yield.

\section{CONCLUSION}

The present studies indicated that the treatments $T$. viride (@6 g/kg seed)+1 spray of P. fluorescens (@1 x 10 cfu/ml) at 21 days after sowing/T. harzianum (@6g/kg seed) + spray of P.fluorescens (@1 x 10 cfu/ml) at 21 days after sowing are the most effective treatments in reducing the pearl millet downy mildew incidence and increasing the grain and fodder yield.

\section{ACKNOWLEDGEMENTS}

The authors are grateful to Director and Head, Division of Plant Pathology, Rajasthan Agricultural Research Institute, Durgapura and SKN Agriculture University, Jobner for providing necessary facilities to carry out the experiment.

\section{REFERENCES}

Butler EJ. 1907. Some diseases of cereals caused by Sclerospora graminicola. Mem Agric Indian Bot Ser. 2:1-24.

Gupta SK, Singh D. 1996. Studies on the influence of downy mildew infection on yield and yield-contributing plant characters of pearl millet in India. Int J Pest Mgmt. 42:89-93. https://doi.org/10.1080/09670879609371977

Johnson JC, Monson WG, Burton GW, Mccormick WC. 1976. Performance of dairy heifers grazing pastures of either Gahi 1, Gahi 3 or Tifleaf 1 millet. J Dairy Sci. 59:19.

Latake SB, Kolase SV. 2007. Screening of bio-agents for control of downy mildew of pearl millet. Int J Agric Sci. 3(2):32-5. 
Mane SS, Chaudhari KN, Patil BD. 2007. Efficacy of biological control agents against downy mildew of bajra. J Pl Dis Sci. 2(2):245-6.

Mani MT, Hepziba SJ. 2009. Biological management of pearl millet downy mildew caused by Sclerospora graminicola. Archives Phytopathol Pl Protec. 42(2): 129 -35. https://doi.org/10.1080/03235400600982618

Nandini B, Hariprasad P, Niranjana SR, Shetty HS, Geetha NP. 2013. Elicitation of resistance in pearl millet by oligosaccharides of Trichoderma spp. against downy mildew disease. J Pl Int. 8(1):45-55. https://doi.org/10. 1080/17429145.2012.710655

Nandakumar R, Babu S, Viswanathan R, Raguchander T, Samiyappan R. 2001. Induction of systemic resistance in rice against sheath blight disease by Pseudomonas fluorescens. Soil Biol Biochem. 33:603-12. https://doi. org/10.1016/S0038-0717(00)00202-9

Niranjan Raj S, Shetty NP, Shetty HS. 2004. Seed bio-priming with Pseudomonas fuorescens isolates enhances growth of pearl millet plants and induces resistance against downy mildew. Int J Pest Mgmt. 50(1):41-8. https://doi. org/10.1080/09670870310001626365

Raj SN, Lavanya SN, Amruthesh KN, Niranjana SR, Shetty HS. 2011. Comparative evaluation of Pseudomonas fluorescens and their lipopolysaccharides as implicated in induction of resistance against pearl millet downy mildew. Archives Phytopathol Pl Prot. 44(13):1285-99. https://doi.org/10.1080/03235408.2010.493750

Raj SN, Shetty NP, Shetty HS. 2005. Synergistic effects of trichoshield on enhancement of growth and resistance to downy mildew in pearl millet. Bio-Control. 50(3):493509. https://doi.org/10.1007/s10526-004-0460-X
Rachie KO, Majmudar YV. 1980. Pearl millet. University Park, Pennsylvania, USA: Pennsylvania State University Press. 307.

Raj K, Arya RK, Kumar R. 2014. Pearl millet improvement for disease resistance. Forage Res. 40:133-46.

Safeeulla KM. 1976. Biology and control of downy mildews of pearl millet, sorghum and finger millet. University of Mysore, Mysore, Karnataka, India, p. 304.

Sangwan P, Kushal R. 2016. Evaluation of bioagents for management of downy mildew of pearl millet caused by Sclerospora graminicola (Sacc.) Schroet. Forage Res. 42(1):44-7.

Sasode RS, Pandya RK, Fatehpuria PK. 2018. Management of downy mildew by the application of bioagents, chemicals and botanical. Int $J$ Chemical Studies. 6(1):606-8.

Singh SD, Ball S, Thakur DP. 1987. Problems and strategies in the control of downy mildew. (Summaries in En, Fr.) in Proceedings of the International Pearl Millet Workshop. 7-11 Apr 1986. p. 161-72.

Umesha S, Dharmesh SM, Shetty SA, Krishnapp, M, Shetty HS. 1998. Bio control of downy mildew disease of pearl millet using Pseudomonas fluorescens. Crop Protection. 17:38792. https://doi.org/10.1016/S0261-2194(98)00014-3

Williams RJ, Singh SD. 1981. Control of pearl millet downy mildew by seed treatment with metalaxyl. Ann Appl Biol. 97:263-8. https://doi.org/10.1111/j.1744-7348.1981. tb05111.x 